\title{
Implikasi Putusan Mahkamah Konstitusi Nomor 92/PUU-XIV/2016 terhadap Independensi Komisi Pemilihan Umum
}

\author{
Allan Fatchan Gani Wardhana \\ Fakultas Hukum Universitas Islam Indonesia \\ allanfatchanganiw@gmail.com
}

\begin{abstract}
The General Elections Commission (KPU) is an independent state institution directly regulated in Article 22E of the 1945 Constitution of the Republic of Indonesia. Its position as an independent state institution affirms that the KPU is not under the influence of the Parliament of Indonesia (DPR) and the government in carrying out its duties and authorities. Article 9 Sub-Article a of Law Number 10 Year 2016 (Regional Head Election Law) stipulates the requirement of the KPU to consult the DPR and the Government in drafting and enacting KPU regulations and technical guidelines for each election stage in forums of hearings whose decisions are binding. The Constitutional Court through Decision Number 92/PUU-XIV / 2016 finally canceled the word "binding" it; the existence of the word "binding" is considered contrary to the Constitution and interfere with the independence of the Commission. The research concludes, first, the independence of KPU as an organizer of election is one of the requirements for the realization of free and fair election. Secondly, the juridical implication in Decision $92 /$ PUU-XIV/ 2016 confirms that the binding word in Article 9 sub-paragraph a of the Regional Head Election Law does not have binding legal force, so that the spirit and independence of KPU as an election organizer can be maintained.
\end{abstract}

Keywords: The General Elections Commission; independence; decision of Constitutional Court 


\section{Abstrak}

Komisi Pemilihan Umum (KPU) merupakan lembaga negara yang independen yang diatur secara langsung dalam Pasal 22E UUD NRI Tahun 1945. Posisinya sebagai lembaga negara independen menegaskan bahwa KPU tidak berada di bawah pengaruh Dewan Perwakilan Rakyat (DPR) dan pemerintah dalam menjalankan tugas dan wewenangnya. Pasal 9 huruf a Undang-Undang Nomor 10 Tahun 2016 (UU Pilkada) mengatur keharusan KPU untuk berkonsultasi dengan DPR dan pemerintah dalam menyusun dan menetapkan peraturan KPU dan pedoman teknis untuk setiap tahapan pemilihan dalam forum rapat dengar pendapat yang keputusannya bersifat mengikat. Mahkamah Konstitusi melalui Putusan Nomor 92 / PUU-XIV/2016 akhirnya membatalkan kata "mengikat" tersebut, ka-rena bertentangan dengan Konstitusi dan mengganggu independensi KPU. Penelitian ini menyimpulkan, pertama, independensi KPU sebagai lembaga penyelenggara pemilu merupakan salah satu syarat bagi terwujudnya pemilu yang bebas dan adil. Kedua, implikasi yuridis dalam putusan 92/ PUU-XIV/2016 menegaskan bahwa kata "mengikat" dalam Pasal 9 huruf a UU Pilkada bertentangan dengan UUD NRI Tahun 1945 dan tidak memiliki kekuatan hukum yang mengikat, sehingga marwah dan independensi KPU sebagai lembaga penyelenggara pemilu dapat terjaga.

Kata kunci: Komisi Pemilihan Umum; independensi; putusan Mahkamah Konstitusi

\section{A. Pendahuluan}

Prinsip kedaulatan rakyat di dalam Undang-Undang Dasar Negara Republik Indonesia (UUD NRI) Tahun 1945 dimuat baik dalam pembukaan (alinea ke 4) maupun batang tubuh. Dalam Pasal 1 ayat (2) UUD NRI 1945 ditetapkan bahwa "kedaulatan berada di tangan rakyat dan dilaksanakan menurut UUD”. 'Terhadap istilah kedaulatan rakyat (people souveriegnty) tersebut beberapa ahli hukum menegaskan bahwa ia indentik dengan istilah demokrasi.

Saat ini kebanyakan doktrin kedaulatan rakyat digunakan sebagai dasar konsep negara demokrasi di zaman modern. Pada zaman

1 Eddy Purnama, Negara Kedaulatan Rakyat (Malang: Nusa Media, cetakan kedua, 2007), hlm. 40. 
modern ini, hampir semua negara mengklaim menjadi penganut paham demokrasi. ${ }^{2}$ Memang harus diakui sampai sekarang istilah demokrasi itu sudah menjadi bahasa umum yang menunjuk pada pengertian sistem politik yang ideal di mana-mana. Berdasarkan penjelasan tersebut, terdapat korelasi yang sangat dekat antara konsepsi kedaulatan rakyat dengan konsepsi demokrasi. Bagir Manan menyatakan bahwa negara yang demokratis adalah negara yang menempatkan kekuasaan tertinggi pada rakyat. ${ }^{3}$ Pernyataan ini jelas mengindikasikan ada keterkaitan yang sangat erat antara demokrasi dan kedaulatan rakyat. Kedaulatan rakyat diposisikan sebagai syarat bagi suatu negara yang hendak menganut sistem demokrasi.

Di antara bentuk perwujudan kedaulatan rakyat tersebut adalah pemilihan umum (pemilu). ${ }^{4}$ Secara teoretis pemilu dianggap merupakan tahap paling awal dari berbagai rangkaian kehidupan ketatanegaraan yang demokratis, sehingga pemilu merupakan motor penggerak mekanisme sistem politik demokrasi ${ }^{5}$ untuk memilih pemimpin atau wakil-wakil rakyat dalam sebuah negara. Di Indonesia, pemilu terdiri dari pemilu legislatif, pemilu presiden dan wakil presiden, dan pemilu kepala daerah dan wakil kepala daerah. ${ }^{6}$

2 Jimly Asshiddiqie, Konstitusi dan Konstitusionalisme Indonesia (Jakarta: Sinar Grafika, cetakan kedua, 2011), hlm. 116.

3 Bagir Manan, Kedaulatan Rakyat, Hak Asasi Manusia dan Negara Hukum (Jakarta: Gaya Media Pratama, 1996), hlm. 56.

4 Dalam bahasa yang lain, pemilihan umum adalah salah satu pilar utama demokrasi. Sentralitas dari posisi pemilihan umum dalam membedakan sistem politik yang demokratis atau bukan, tampak jelas dari beberapa definisi demokrasi yang diajukan oleh para sarjana. Salah satu konsepsi modern awal mengenai demokrasi diajukan oleh Joseph Schumpeter (mazhab Schumpeterian) yang menempatkan penyelenggaraan pemilihan umum yang bebas dan berkala sebagai kriteria utama bagi suatu sistem politik untuk dapat disebut demokrasi. Suparman Marzuki, "Peran Komisi Pemilihan Umum dan Pengawas Pemilu untuk Pemilu yang Demokratis", Ius Quia Iustum, 15, 3 (2008), hlm. 394.

5 B. Hestu Cipto Handoyo, sebagaimana dikutip Nur'aini, "Politik Hukum Larangan Pengunduran Diri Anggota Komisi Pemilihan Umum”, Jurnal Cita Hukum, 2, 1 (2013), hlm. 287.

6 Berdasarkan sejarah dan perkembangannya, dari sudut pandang hukum ketatanegaraan, perubahan mekanisme pemilihan kepala daerah dan wakil kepala daerah dari sistem perwakilan ke sistem pemilihan langsung meru- 
Konstitusi UUD NRI 1945 mengatur bagaimana pemilu tersebut dilaksanakan. Menurut pasal 22E UUD NRI 1945, pemilu dilaksanakan secara langsung, umum, bebas, rahasia, jujur dan adil. ${ }^{7}$ Pasal ini muncul akibat sejarah pelaksanaan pemilu di Indonesia yang berlangsung secara tidak demokratis utamanya pada saat orde baru. Dalam pasal ini juga diatur bahwa yang melaksanakan pemilihan umum adalah komisi pemilihan umum. ${ }^{8}$

Ketentuan mengenai pemilihan umum dalam perkembangannya diatur dalam undang-undang tersendiri, dan yang saat ini berlaku adalah UU Nomor 15 Tahun 2011 tentang Penyelenggara Pemilihan Umum. UU ini juga mengatur kelembagaan penyelenggara pemilu, yaitu KPU, beserta tugas dan kewenangannya. Di antara tugas dan wewenang KPU yang diatur dalam UU ini adalah, menyusun dan menetapkan pedoman teknis untuk setiap tahapan pemilihan setelah terlebih dahulu berkonsultasi dengan DPR dan Pemerintah,yang diperuntukkan untuk pemilihan gubernur, bupati, dan walikota. ${ }^{9}$ Se-

pakan kemajuan yang sangat siginifikan dalam kehidupan berdemokrasi dan berkonstitusi dalam praktik ketatanegaraan Indonesia. Perubahan ini tentu akan berdampak pada sistem politik lokal dan membuka ruang yang lebih luas bagi partisipasi rakyat dalam proses berdemokrasi. Pemilihan kepala daerah secara langsung diharapkan menghasilkan figur kepemimpinan yang aspiratif, berkualitas, dan legitimatif. Dengan pemilihan langsung ini akan lebih mendekatkan pemerintah dengan yang diperintah, dan akuntabilitas kepala daerah benar-benar tertuju pada rakyat. Lihat Dahlan Thaib, Ketatanegaraan Indonesia Perspektif Konstitusional (Yogyakarta: Total Media, 2009), hlm. 49.

7 Pasal 22E ayat (1) UUD NRI 1945: "pemilihan umum dilaksanakan secara langsung, umum, bebas, rahasia, jujur, dan adil setiap lima tahun sekali”.

8 Pasal 22E ayat (5) UUD NRI 1945: "pemilihan umum diselenggarakanoleh suatu komisi pemilihan umum yang bersifat nasional, tetap, dan mandiri”.

9 Tugas dan wewenang KPU dalam pemilihan gubernur, bupati, dan walikota berdasarkan Pasal 8 ayat (3) UU Nomor 15 Tahun 2011 tentang Penyelenggara Pemilihan Umum adalah a) menyusun dan menetapkan pedoman teknis untuk setiap tahapan pemilihan setelah terlebih dahulu berkonsultasi dengan DPR dan Pemerintah; b) mengoordinasikan dan memantau tahapan pemilihan; c) melakukan evaluasi tahunan penyelenggaraan pemilihan; d) menerima laporan hasil pemilihan dari KPU Provinsi dan KPU Kabupaten/Kota; e) mengenakan sanksi administratif dan/atau menonaktifkan sementara anggota KPU Provinsi yang terbukti melakukan tindakan yang mengakibatkan terganggunya tahapan penyelenggaraan pemilihan berdasarkan rekomendasi Bawaslu dan/atau ketentuan peraturan perun- 
lain soal teknis, UU ini juga memberi wewenang kepada KPU untuk membuat kebijakan dalam bentuk peraturan KPU (PKPU). ${ }^{10}$ Terkait dengan kewenangan yang disebut terakhir ini, KPU tentu tidak boleh diintervensi oleh kekuasaan lainnya, meskipun UU ini mengatur penetapan PKPU dilakukan setelah berkonsultasi dengan DPR dan pemerintah. ${ }^{11} \mathrm{Hal}$ ini penting untuk menjaga kemandirianKPU, sehingga pemilu dilaksanakan secara jujur dan adil.

Dalam perkembangannya, kewenangan KPU dalam penyelenggaraan pemilihan kepala daerah (pilkada) diatur juga dalam UU Nomor 8 Tahun 2015 juncto UU Nomor 10 Tahun 2016 tentang Pemilihan Gubernur, Bupati, dan Walikota (UU Pilkada). Dalam UU ini diatur pula tentang kewenangan KPU dalam menyusun dan menetapkan peraturan KPU dan pedoman teknis, yang mengharuskan KPU berkonsultasi dengan DPR dan pemerintah dalam forum rapat dengar pendapat yang keputusannya bersifat mengikat (Pasal 9 huruf a). ${ }^{12}$ Munculnya ketentuan ini kemudian menimbulkan kritik. Ia dianggap sebagai sebuah penyelundupan hukum, disebabkan pada UU Pemilu, yang dibentuk terlebih dulu, tidak terdapat frasa "mengikat". Dengan ketentuan dalam UU Pilkada tersebut, maka KPU harus tunduk pada DPR dan pemerintah ketika konsultasi sekaligus membuat peraturan KPU atau pedoman teknis untuk setiap tahap pemilihan dalam pilkada. KPU juga berarti wajib melaksanakan apapun yang diminta oleh DPR dan pemerintah dalam membuat PKPU dan pedo-

dang-undangan; dan f) melaksanakan tugas dan wewenang lain sesuai dengan ketentuan peraturan perundang-undangan.

10 Kewenangan KPU dalam membuat Peraturan KPU diatur dalam Pasal 119 ayat (1) UU Nomor 15 Tahun 2011, "untuk menyelenggaraka pemilu, KPU membentuk Peraturan KPU dan Keputusan KPU”. Peraturan KPU ini berdasarkan ketentuan ayat (2) merupakan pelaksanaan peraturan perundangundangan, "Peraturan KPU sebagaimana dimaksud pada ayat (1) merupakan pelaksanaan Peraturan Perundang-undangan".

11 Pasal 119 ayat (4) UU Nomor 15 Tahun 2011, "Peraturan KPU sebagaimana dimaksud pada ayat (2) ditetapkan setelah berkonsultasi dengan DPR dan Pemerintah".

12 Pasal 9 huruf a UU Pilkada: "menyusun dan menetapkan peraturan KPU dan pedoman teknis untuk setiap tahapan pemilihan setelah berkonsultasi dengan Dewan Perwakilan Rakyat dan Pemerintah dalam forum rapat dengar pendapat yang keputusanya bersifat mengikat”. 
man teknis. Hal ini jelas berpotensi mengganggu independensi KPU sebagai lembaga penyelenggara pemilu yang mandiri.

Sebagai ikhtiar mewujudkan pemilu yang jujur dan adil, penyusunan peraturan KPU dan pedoman teknisnya haruslah terbebas dari intervensi pihak mana pun, termasuk DPR dan pemerintah. Keberadaan forum konsultasi KPU dengan DPR dan pemerintah seharusnya dijadikan sebagai langkah untuk memperbanyak referensi yang akan menjadi bahan pertimbangan KPU. DPR yang merupakan lembaga politik dikhawatirkan akan memberikan usulan-usulan atau rekomendasi yang sarat dengan kepentingan partai politik tertentu. Ketentuan ini yang lalu mendorong KPU melakukan uji materiil (judicial review) pasal 9 huruf a UU Pilkada ke Mahkamah Konstitusi (MK).

Dalam uji materiil ini, MK telah mengeluarkan putusan Nomor 92 / PUU-XIV/2016. Berdasarkan putusan ini MK menyatakan, frasa “...yang keputusannya bersifat mengikat” pada Pasal 9 huruf a UU Pilkada bertentangan dengan UUD NRI Tahun 1945 dan tidak mempunyai kekuatan hukum mengikat. ${ }^{13}$

Artikel ini akan membahas implikasi putusan MK tersebut terhadap independensi KPU dalam menyelenggarakan pemilu, khususnya dalam membuat Peraturan KPU dan pedoman teknis terkait pilkada. Pertanyaan yang akan didiskusikan dan dijawab adalah, pertama, apa urgensi prinsip independensi bagi KPU, dan kedua, apa implikasi yuridis Putusan MK Nomor 92/PUU-XIV/2016 terhadap independensi KPU. Secara metodologis, pertanyaan tersebut dibahas dengan menggunakan penelitian hukum normatif, karena peneliti melakukan penelitian dengan studi literatur, peraturan perundangundangan, dan putusan MK yang berhubungan dengan objek penelitian. Sumber data yang digunakan adalah bahan-bahan hukum, baik yang primer, sekunder, maupun tersier. Pendekatan yang digunakan adalah pendekatan kasus (case approach) dan pendekatan perundangundangan (statute approach).

13 Putusan Mahkamah Konstitusi Republik Indonesia Nomor Perkara 92/ PUU-XIV/2016, hlm. 80-81. 


\section{B. Urgensi Prinsip Independensi bagi Komisi Pemilihan Umum}

Independensi suatu "lembaga negara" dimaknai secara berbeda-beda oleh para ahli. Frases dan Meyer membedakan independensi ke dalam kategori goal independence, yaitu independensi dilihat dari segi penetapan tujuan, dan instrument independence, yaitu independensi dalam cara mencapai tujuan yang telah ditetapkan. ${ }^{14}$ V. Grilli, dkk dan Robert Elgie membedakan independensi itu dari segi politik (political independence) dan dari segi ekonomi (economic independence). W. Baka membedakan independensi ke dalam tiga aspek, yaitu institutional independence, functional independence, dan financial independence. Sementara Mboweni membedakannya menjadi empat, yaitu functional independence, personal independence, instrumental independence, dan financial independence. ${ }^{15}$

Istilah independen atau independensi merupakan serapan dari kata independence yang berarti "the state of quality of being independent; a countryfreedom to manage all its affairs, whether external or internal without countrol byother country". ${ }^{16}$ Kamus Besar Bahasa Indonesia (KBBI) mendefinisikan independen sebagai "yang berdiri sendiri, yang berjiwa bebas, tidak terikat, merdeka, bebas". ${ }^{17}$ Makna seperti ini hampir sama dengan makna kata mandiri, yaitu "dalam keadaan dapat berdiri sendiri; tidak bergantung pada orang lain". ${ }^{18} \mathrm{KBBI}$ mendefinisikan kata independensi sama dengan kemandirian, ${ }^{19}$ yang berarti "hal atau keadaan dapat berdiri sendiri tanpa bergantung pada orang lain". ${ }^{20}$

Dengan demikian, independensi berarti sikap yang tidak bisa dipengaruhi, tidak dikendalikan pihak lain, tidak bergantung pada

14 Jimly Ashiddiqie, Pokok-Pokok Hukum Tata Negara Indonesia (Jakarta: BIP Gramedia, 2008), hlm. 879.

15 Jimly Ashiddiqie, Pokok-Pokok Hukum Tata Negara, hlm. 879.

16 Bryan A Garner, Black Law Dictionary (United States of America: West Group, edisi ketujuh, 1999), hlm. 773.

17 https://kbbi.kemdikbud.go.id/entri/independen

18 https://kbbi.kemdikbud.go.id/entri/mandiri

19 https://kbbi.kemdikbud.go.id/entri/independensi

20 https://kbbi.kemdikbud.go.id/entri/kemandirian 
pihak lain. Ia merupakan sifat yang tidak dapat diintervensi oleh pihak manapun, sekalipun dari pemegang kekuasaan tertinggi. Apabila dalam bersikap tersebut ada intervensi oleh suatu lembaga, misalnya, maka ia tidak bisa lagi disebut bersifat independen.

Dalam kaitannya dengan lembaga negara independen, KPU merupakan salah satu dari sekian lembaga negara independen di Indonesia. Pembentukan KPU sebagai lembaga independen didasari oleh karena KPU sebagai penyelenggara pemilu tidak berada dan/ atau di bawah pengaruh seorang, kelompok, golongan, partai politik, dan pemerintah. ${ }^{21}$ Masih berkenaan dengan hal tersebut, menurut Zainal Arifin Mochtar, sebuah lembaga dinyatakan independen apabila memenuhi empat syarat. Pertama, pengisian pimpinannya tidak dilakukan oleh satu lembaga saja; kedua, pemberhentian anggota lembaga hanya dapat dilakukan berdasarkan sebab-sebab yang diatur dalam undang-undang pembentukan lembaga bersangkutan; ketiga, presiden dibatasi untuk tidak secara bebas memutuskan pemberhentian pimpinan lembaga; dan keempat, pimpinan bersifat kolektif, tidak dikuasai/ mayoritas berasal dari partai politik tertentu; dan masa jabatan pemimpin tidak habis secara bersamaan tetapi bergantian. ${ }^{22}$

Milakovich dan Gordon, sebagaimana dikutip Gunawan A. Tauda, secara rinci menentukan karakteristik lembaga negara independen atau komisi negara, yaitu: ${ }^{23}$

1. Komisi ini memiliki karakter kepemimpinan yang bersifat kolegial, sehingga keputusan-keputusan yang diambil secara kolektif.

2. Anggota baru atau para komisioner lembaga ini tidak melayani apa yang menjadi keinginan presiden sebagaimana jabatan yang dipilih oleh presiden lainnya.

21 Oktino Setyo Irawan, "Analisis Kedudukan Komisi Pemilihan Umum (KPU) Sebagai Lembaga Independen dalam Sistem Ketatanegaraan Indonesia”, Dinamika Hukum, 2, 1 (2011), hlm. 87

22 Saldi Isra, "Kata Pengantar", dalam Zainal Arifin Mochtar, Lembaga Negara Independen (Jakarta: PT. Rajagrafindo Persada, 2016), hlm. x.

23 Gunawan A. Tauda, Komisi Negara Independen (Yogyakarta: Genta Press, 2012), hlm. 97. 
3. Masa jabatan para komisioner ini biasanya definitif dan cukup panjang.

4. Periode jabatanya bersifat staggered, artinya setiap tahun setiap komisioner berganti secara bertahap dan oleh karena itu seorang presiden tidak bisa menguasai secara penuh kepemimpinan lembaga-lembaga terkait.

5. Jumlah anggota atau komisioner ini bersifat ganjil dan keputusan diambil secara mayoritas suara.

6. Keanggotaan lembaga ini biasanya menjaga keseimbangan perwakilan yang bersifat partisan.

Jimly Asshiddiqie menyebutkan keseluruhan kategori independensi terkait dalam tiga bentuk, yaitu: ${ }^{24}$

1. Independensi institusional atau struktural, yang tercermin dalam mekanisme hubungan eksternal antar lembaga negara.

2. Independensi fungsional, yang tercermin dalam proses pengambilan keputusan, yang dapat berupa (a) goal independence, yaitu bebas dalam menetapkan tujuan atau kebijakan pokok, dan (b) instrument independence, yaitu bebas dalam menetapkan instrumen kebijakan yang tidak ditetapkan sendiri.

3. Independensi administratif, yaitu merdeka dalam menentukan kebijakan administratif untuk mendukung kedua macam independensi di atas, yaitu berupa (a) independensi keuangan, yaitu merdeka dalam menentukan anggaran pendukung, dan (b) independensi personalia, yaitu merdeka dalam mengatur dan menentukan pengangkatan serta pemberhentian personalia kepegawaian sendiri.

Dengan demikian, independensi, kedudukan, dan ruang lingkup kewenangan komisi atau lembaga negara independen bervariasi, sehingga dapat dikatakan bahwa secara teori tidak ada tolok ukur yang sama dalam membentuk karakteristik independensi, kedudukan, dan ruang lingkup kewenangan lembaga-lembaga tersebut. Pada akhirnya dapat dikatakan, pengertian komisi negara dapat dirumuskan sebagai lembaga negara independen yang muncul karena tidak

24 Jimly Asshiddiqie, Pokok-Pokok Hukum Tata Negara, hlm. 879-880. 
efektifnya lembaga yang telah ada dan bertujuan untuk menjalankan prinsip check and balances. Karakteristik komisi negara sendiri meliputi beberapa hal, yaitu: independen, artinya tidak terikat dari cabang kekuasaan manapun; kepemimpinanya bersifat kolektif kolegial dan nonpartisan; dan menjalankan prinsip check and balances. Dengan karakteristik tersebut, lembaga negara independen atau komisi negara lebih leluasa dalam menjalankan fungsinya karena tidak terikat sama sekali dengan cabang kekuasaan mana pun. Independensi dengan demikian dapat dijadikan tolok ukur suatu komisi negara.

KPU sebagai lembaga negara yang independen diatur secara langsung dalam Pasal 22E UUD NRI 1945 sebagai organ yang nasional, tetap, dan mandiri. Sebagai lembaga negara independen, KPU tidak berada di bawah pengaruh DPR dan pemerintah dalam menjalankan tugas dan wewenangnya. Frasa "mandiri" yang terdapat dalam Pasal 22E UUD NRI 1945 dimaksudkan agar KPU dalam menyelenggarakan pemilu tidak diintervensi oleh pihak lain. Keanggotaan KPU pun juga tidak berasal dari partai politik dan pemerintah sehingga diharapkan tidak akan menimbulkan conflict of interest di dalamnya. Independensi inilah yang digunakan untuk menjamin terjaganya kinerja KPU dalam menjalankan tugas sebagai penyelenggara pemilu.

The International Institute for Democracy and Electoral Assistance (IDEA) menekankan pentingnya independensi dalam penyelenggaraan pemilu, sebab ia merupakan salah satu syarat bagi terwujudnya pemilu yang bebas dan adil (free and fair election). Dengan kata lain, KPU sebagai institusi penyelenggara pemilu merupakan pihak yang bertanggungjawab atas terlaksananya pemilu secara adil dan lancar. Secara umum tanggung jawab penyelenggara pemilu adalah implementasi proses pemilihan (electoral process) yang telah digariskan oleh peraturan perundang-undangan. ${ }^{25}$ Ini artinya KPU tidak boleh tunduk pada arahan dari pihak lain mana pun, baik DPR, pemerintah, atau partai politik. KPU harus mampu menjalankan kegiatan yang bebas

25 Winarti, "Menyoal Independensi dan Profesionalitas Komisi Pemilihan Umum Daerah dalam Penyelenggaraan Pemilu Kepala Daerah”, Jurnal Konstitusi, 2, 3 (2010), hlm. 52. 
dari campur tangan pihak mana pun. Sifat konsultasi yang bersifat mengikat KPU jelas bertentangan dengan prinsip independensi.

Sejumlah analisis kemudian mengemukakan bahwa terdapatnya frasa "mengikat" itu dikhawatirkan akan memangkas kemandirian KPU sebagai penyelenggara pemilu. Sifat konsultasi yang mengikat dinilai oleh sejumlah kalangan menjadi celah intervensi dalam penyusunan PKPU. Padahal KPU dalam membuat aturan pelaksanaan teknis tidak boleh mencerminkan kekuatan politik tertentu, melainkan harus berdiri sendiri dan tidak terpengaruh oleh kekuasaan mana pun, termasuk disini adalah kekuasaan DPR dan pemerintah.

\section{Implikasi Yuridis Putusan Mahkamah Konstitusi Nomor 92/PUU-XIV/2016 terhadap Independensi Komisi Pemilihan Umum}

Mahkamah Konstitusi (MK) melalui putusan nomor 92/PUUXIV/ 2016 yang dibacakan pada 10 Juli 2017 menyatakan frasa “...setelah berkonsultasi dengan DPR dan pemerintah dalam forum rapat dengar pendapat yang keputusannya bersifat mengikat" dalam Pasal 9 huruf a UU Nomor 10 Tahun 2016 tentang Perubahan Kedua atas UU Nomor 1 Tahun 2015 tentang Penetapan Peraturan Pemerintah Pengganti UU Nomor 1 Tahun 2014 tentang Pemilihan Gubernur, Bupati dan Walikota menjadi UU, "menyusun dan menetapkan peraturan KPU dan pedoman teknis untuk setiap tahapan pemilihan setelah berkonsultasi dengan Dewan Perwakilan Rakyat dan Pemerintah dalam forum rapat dengar pendapat yang keputusanya bersifat mengikat", bertentangan dengan Pasal 22E ayat (5) UUD NRI 1945 dan tidak mempunyai kekuatan hukum mengikat. ${ }^{26}$ Meski putusan ini mengabulkan sebagian saja dari permohonan yang diajukan KPU, karena pemohon menghendaki pembatalan norma yang mewajibkan KPU untuk melakukan konsultasi, ia mengandung konsekuensi yang cukup signifikan dalam kerja-kerja KPU.

Dengan putusan tersebut, MK terlihat jelas menjalankan fung-

26 Petitum Nomor 2 dalam Putusan Mahkamah Konstitusi Republik Indonesia No. 92/PUU-XIV/2016, hlm. 29. 
si sebagai pengawal konstitusi sekaligus demokrasi. Hal ini sejalan dengan fungsi MK sebagai satu-satunya lembaga yang bertugas sebagai pengawal konstitusi (the guardian of the constitution). Selain sebagai lembaga pengawal konstitusi, MK juga berfungsi sebagai penafsir konstitusi, serta pengawal demokrasi (the guardian and the sole interpreter of the constitution, as well as the guardian of the process of democrazitation). ${ }^{27}$ Putusan tersebut juga semakin mempertegas kemajuan-kemajuan yang dicapai oleh MK sebagai institusi kehakiman yang lahir dari rahim reformasi. MK sudah membuktikan sebagai institusi hukum yang dapat dipercaya dan terhormat (realible and honoured court) di Indonesia, disebabkan putusan-putusannya yang sangat progresif dan dapat menjadi acuan hukum bagi percepatan reformasi hukum di Indonesia. ${ }^{28}$

Berkaitan dengan putusan tersebut, sejumlah pertimbangan hukum yang menjadi dasar MK dalam mengambil putusan menarik untuk ditelaah. Dalam salinan putusan No. 92/PUU-XIV/2016, hal pertama yang menjadi pertimbangan MK ialah:

Bahwa dalam menilai dan memahami kemandirian KPU sebagaimana dimaksud Pasal 22E ayat (5) UUD NRI 1945 tidak cukup hanya dilakukan secara tekstual tatkala perihal kemandirian yang dimaksud dalam UUD NRI 1945 dituangkan lebih lanjut ke dalam suatu norma undang-undang melainkan harus dikaitkan konteksnya dengan kaidah yang berlaku dalam penafsiran konstitusi yang menuntut pemahaman terhadap konstitusi sebagai satu kesatuan (the unity of the constitution), koherensinya secara praktis (practical coherence), dan keberlakuannya yang tepat (the appropriate working) dari pengertian yang hendak diberikan oleh Konstitusi (UUD NRI 1945) terhadap istilah "mandiri" dimaksud. ${ }^{29}$

Lebih lanjut dalam pertimbangan tersebut dinyatakan bahwa konteks latar belakang sejarah (historical background), aspek teleologis (teleological aspect), dan antisipasi terhadap kemungkinan-kemungkinan yang dapat terjadi pada masa yang akan datang (future anticipa-

27 Jimly Asshiddiqie, Perkembangan \& Konsolidasi Lembaga Negara Pasca Reformasi (Jakarta: Sinar Grafika, 2012), hlm. 132.

28 Ni'matul Huda dan R. Nazriyah, Teori \& Pengujian Peraturan Perundangundangan (Bandung: Nusa Media, 2011), hlm. 146.

29 Pertimbangan Hukum Nomor 3.9.1 dalam Putusan Mahkamah Konstitusi Republik Indonesia No. 92/PUU-XIV/2016, hlm. 71. 
tion) merupakan keniscayaan yang harus dipertimbangkan secara cermat. Pada aspek latar belakang (historical background), MK mencoba mencermati secara subjektif ${ }^{30}$ bagaimana sejarah hukum dibentuknya KPU sebagai lembaga penyelenggara pemilu di Indonesia. MK melihat bahwa catatan panjang sejarah penyelenggaraan pemilu yang selalu diwarnai praktik curang yang melibatkan penyelenggara menjadi salah satu pertimbangan untuk menyerahkan penyelenggaraan pemilu kepada sebuah lembaga yang bersifat mandiri, bukan lagi oleh pemerintah maupun partai politik peserta pemilu. ${ }^{31}$ Dari pertimbangan ini nampak MK menggunakan penafsiran historis dalam hal ini sejarah hukumnya, yakni mencari makna yang dikaitkan dengan konteks kemasyarakatan pada masa lampau. ${ }^{32}$

MK juga dalam putusan ini menggunakan metode penafsiran teleologis, yakni dengan mencermati kaidah demokrasi dan kedaulatan rakyat yang menjadi basis dalam pelaksanaan pemilu. Penafsiran yang difokuskan pada penguraian atau formulasi kaidah-kaidah hukum menurut tujuan dan jangkauannya ${ }^{33}$ ini dicermati MK dengan cara memahami UUD NRI 1945 sebagai kesatuan utuh yang tak dapat dipisahkan.

Pemilu sebagai sarana pelaksanaan kedaulatan rakyat sebagaimana dimaksud dalam Pasal 1 ayat (2) UUD 1945 harus dilaksanakan secara langsung, umum, bebas, rahasia, jujur dan adil. Pemilu yang jujur dan adil hanya akan dapat diwujudkan bila diselenggarakan oleh sebuah lembaga yang bebas dari intervensi lembaga manapun, lebih-lebih institusi yang di dalamnya terdapat peserta Pemilu. Peran DPR dan Pemerintah berhenti hanya sampai tahap pembentukan Undang-Undang yang berhubungan dengan Pemilu dan melaksanakan seleksi calon anggota penyelenggara Pemilu. Dengan demikian apabila sudah masuk pada proses dan tahapan, pemilu sepenuhnya harus dikendalikan oleh KPU sebagai lembaga independen. Dengan melihat hubungan sistematis antara Pasal 22E ayat (5) UUD 1945 dengan Pasal 1 ayat (2) dan Pasal 22E ayat (1) UUD 1945,

30 Mahkamah Konstitusi Republik Indonesia, Hukum Acara Mahkamah Konstitusi (Jakarta: Sekretariat Jenderal dan Kepaniteraan Mahkamah Konstitusi, 2010), hlm. 73.

31 Putusan Mahkamah Konstitusi Republik Indonesia No. 92 / PUU-XIV / 2016, hlm. 73-74.

32 Jimly Asshiddiqie, Pengantar Ilmu Hukum Tata Negara (Jakarta: Rajawali Pers, 2011), hlm. 221.

33 Jimly Asshiddiqie, Pengantar Ilmu Hukum, hlm. 223. 
terlihat bahwa UUD 1945 menghendaki agar pelaksanaan kedaulatan rakyat melalui Pemilu harus terlaksana secara jujur. Di mana, kejujuran dalam pemilu hanya mungkin dapat dicapai apabila pemilu dilaksanakan oleh sebuah lembaga yang bersifat mandiri. ${ }^{34}$

Pertimbangan di atas sangat tepat dan sesuai dengan semangat MK sebagai lembaga pengawal maupun penegak demokrasi. Afan Gaffar memberikan lima hal yang merupakan elemen empirik sebagai konsekuensi dari demokrasi, salah satunya ialah warga masyarakat dapat mengaktualisasikan dirinya secara maksimal di dalam kehidupan politik dengan melakukan partisipasi politik yang mandiri (autonomous participation) tanpa digerakkan. ${ }^{35}$ Partisipasi politik masyarakat yang mandiri ini tidak boleh diintervensi baik secara langsung atau tidak oleh penyelenggara pemilu. Salah satu bentuk intervensi tidak langsung tersebut misalnya intervensi kepentingan parpol melalui DPR dengan memengaruhi KPU dalam menetapkan peraturan atau pedoman teknis pemilihan. Dengan demikian, MK tampak telah berhasil memaknai sifat mandiri KPU agar tidak terjebak dalam intervensi secara tidak langsung oleh partisan politik. MK dalam hal ini benar-benar menjalankan fungsinya sebagai pelindung konstitusi dalam arti melindungi demokrasi dan hak-hak asasi manusia, sebagaimana amanah Konstitusi dan UU Mahkamah Konstitusi. ${ }^{36}$

34 Pertimbangan Hukum dalam Putusan Mahkamah Konstitusi Republik Indonesia No. 92 / PUU-XIV/2016, hlm. 74.

35 Afan Gaffar, Politik Indonesia Transisi Menuju Demokrasi (Yogyakarta: Pustaka Pelajar, 2001), hlm. 15.

36 Konsideran UU Nomor 24 Tahun 2003 tentang MK menegaskan, "bahwa MK sebagai salah satu pelaku kekuasaan kehakiman mempunyai peranan penting dalam usaha menegakkan konstitusi dan prinsip negara hukum sesuai dengan tugas dan wewenangnya sebagaimana ditentukan dalam Undang-Undang Dasar Negara Republik Indonesia Tahun 1945”. Lebih lanjut dalam Penjelasan UU MK disebutkan, “...salah satu substansi penting perubahan UUD NRI Tahun 1945 adalah keberadaan MK sebagai lembaga negara yang berfungsi menangani perkara tertentu di bidang ketatanegaraan, dalam rangka menjaga konstitusi agar dilaksanakan secara bertanggung jawab sesuai dengan kehendak rakyat dan cita-cita demokrasi. Keberadaan MK sekaligus untuk menjaga terselenggaranya pemerintahan negara yang stabil, dan juga merupakan koreksi terhadap pengalaman kehidupan ketatanegaraan di masa lalu yang ditimbulkan oleh tafsir ganda terhadap konstitusi." 
Hal demikian beresonansi dengan apa yang dikemukakan oleh Jimly Ashiddiqie, ${ }^{37}$

Dalam konteks ketatanegaraan, MK dikonstruksikan sebagai pengawal konstitusi yang berfungsi menegakkan keadilan konstitusional di tengah kehidupan masyarakat. MK bertugas mendorong dan menjamin agar konstitusi dihormati dan dilaksanakan oleh semua komponen negara secara konsisten dan bertanggungjawab. Di tengah kelemahan sistem konstitusi yang ada, MK berperan sebagai penafsir agar spirit konstitusi selalu hidup dan mewarnai keberlangsungan bernegara dan bermasyarakat.

Sedangkan pada aspek penafsiran futuristik, MK justru tidak kemudian melihat peraturan perundang-undangan yang belum mempunyai kekuatan hukum sebagaimana yang diteorikan. ${ }^{38}$

Bahwa KPU merupakan lembaga yang kemandiriannya dijamin oleh UUD 1945. Kemandirian demikian, baik secara historis, sistematis, teleologis, maupun antisipatif merupakan prasyarat yang tak dapat ditiadakan guna menjamin terselenggaranya pemilu, termasuk pemilihan kepala daerah yang demokratis.... ${ }^{39}$

Tampak dalam pertimbangan tersebut, MK berpandangan bahwa kemandirian KPU tidak boleh dipertaruhkan, karena terselenggaranya pemilu yang demokratis, termasuk pemilihan kepala daerah, merupakan prasyarat bagi terwujudnya budaya demokrasi yang sehat dalam rangka mewujudkan gagasan negara demokrasi yang berdasar atas hukum. Demokrasi tidak boleh kemudian dibelenggu oleh masuknya kepentingan-kepentingan yang dapat mengikis nilainilai demokrasi itu sendiri. Adnan Buyung Nasution menekankan pentingnya sebuah nilai dalam penyelenggaraan demokrasi, dengan menegaskan: ${ }^{40}$

37 Sekretariat Jenderal Mahkamah Konstitusi, "Cetak Biru: Membangun Mahkamah Konstitusi Sebagai Institusi Peradilan Konstitusi yang Modern dan Terpercaya”, dalam Maruarar Siahaan, Hukum Acara Mahkamah Konstitusi Republik Indonesia (Jakarta: Konstitusi Press, 2005), hlm. 12.

38 Putusan Mahkamah Konstitusi Republik Indonesia No. 92 / PUU-XIV / 2016, hlm. 74.

39 Pertimbangan Hukum dalam Putusan Mahkamah Konstitusi Republik Indonesia No. 92 / PUU-XIV/2016, hlm. 75

40 Adnan Buyung Nasution, Pikiran \& Gagasan Demokrasi Konstitusional (Jakarta: PT Kompas Media Nusantara, 2011), hlm 3-4. 
Demokrasi bukan hanya cara, alat, atau proses, tetapi adalah nilainilai atau norma-norma yang harus menjiwai dan mencerminkan keseluruhan proses kehidupan kita bermasyarakat, berbangsa, dan bernegara. Demokrasi bukan hanya kriteria di dalam merumuskan cara atau proses untuk mencapai tujuan, melainkan tujuan itu sendiri haruslah mengandung nilai-nilai atau norma demokrasi. Tegasnya demokrasi bukan hanya cara, tetapi juga tujuan yang harus kita bangun terus-menerus sebagai suatu proses yang pasti akan memakan waktu.

Dengan berbagai pertimbangan di atas, MK telah berupaya membebaskan KPU dari kemungkinan masuknya kepentingan-kepentingan yang dapat mengancam nilai demokrasi. Melalui pengujian tersebut, MK telah mendorong upaya perwujudan negara Indonesia yang demokratis dengan menegaskan sifat mandiri KPU sebagai penyelenggara pemilihan.

Dalam putusan tersebut MK sebenarnya tidak menerima seluruhnya apa yang dimohonkan KPU, yang menghendaki agar konslutasi dengan DPR dan pemerintah dibatalkan, bukan sebatas menghilangkan kekuatan mengikat hasil konsultasi tersebut. Dalam pertimbangannya, MK menyatakan mekanisme konsultasi merupakan kebutuhan karena norma UU yang merupakan produk bersama antara DPR dan presiden tidak selamanya memuat rumusan yang jelas sebagaimana dimaksud pembentuknya, sehingga dapat menimbulkan kesulitan pada pihak KPU untuk mengimplementasikan dalam praktik melalui kewenangannya. ${ }^{41}$ Sikap MK sudah memiliki alasan yang sangat tepat dan prospektif. Hakim memang harus tidak sekadar memaknai konstitusi sebuah bangsa hanya pada saat dokumen konstitusi dibentuk atau pada saat ditafsirkan, tetapi juga harus mampu membangun aturan yang baik untuk pemerintahan bangsa ke depan. ${ }^{42}$

Dikaitkan dengan demokrasi, Robert Dahl mengemukakan bahwa salah satu prinsip demokrasi ialah dipilihnya para penjabat

41 Pertimbangan Hukum Putusan Mahkamah Konstitusi Republik Indonesia No. 92 / PUU-XIV/2016, hlm. 78.

42 Demikian menurut Keith E. Whittington sebagaimana dikutip Feri Amsari, Perubahan UUD 1945: Perubahan Konstitusi Negara Kesatuan Republik Indonesia Melalui Putusan Mahkamah Konstitusi (Jakarta: Rajawali Pers, 2013), hlm. 94-95. 
dari proses pemilihan yang dilakukan secara jujur. ${ }^{43}$ Pemilihan yang jujur tidak dapat terwujud tanpa adanya penyelenggara yang bersifat mandiri atau independen. Hal tersebut dikarenakan dimungkinkan adanya beragam intervensi kepentingan dari orang atau lembaga lain terhadap penyelenggara. Penyelenggara yang terintervensi dapat dipastikan terkekakang kemandiriannya dalam menjalankan tahapan pemilihan secara fair. Untuk itu sikap MK yang menyatakan bahwa adanya frasa "yang keputusannya bersifat mengikat" dalam Pasal 9 huruf a UU Pilkada membawa implikasi teoretik maupun praktik dalam rangka merawat impementasi demokrasi melalui pemilu yang berintegritas. Jika tidak demikian, maka besar kemungkinan akan terjadi fenomena pemilu seperti pada masa orde baru yang ditunggangi intervensi politis, bermuatan ego kemenangan tanpa memperhatikan nilai-nilai moral dan integritas penyelenggaraan pemilu.

Putusan MK yang demikian menimbulkan beberapa implikasi. Pertama, forum konsultasi yang dilakukan oleh KPU terhadap DPR dan Pemerintah menjadi forum konsultasi yang biasa yang tidak mengikat. Frasa "yang keputusannya mengikat" dalam Pasal 9 huruf a UU Pilkada dinyatakan bertentangan dengan konstitusi. Ke depan Pasal 9 huruf a menjadi berisi "menyusun dan menetapkan Peraturan Komisi Pemilihan Umum (PKPU) dan pedoman teknis pemilihan setelah berkonsultasi dengan DPR dan pemerintah dalam Rapat Dengar Pendapat (RDP)". Tidak adanya frasa mengikat melepas belenggu ketertundukan KPU terhadap DPR dan pemerintah. Ketentuan yang demikian sejalan pula dengan tugas dan wewenang KPU dalam penyelenggaraan pemilihan gubernur, bupati, dan walikota yang diatur dalam UU Pemilu, sebagaimana telah dibahas pada bagian terdahulu. Kalaupun masih ada peluang intervensi, terutama dari pihak pemerintah, hal itu tidak lagi pada saat konsultasi RDP. Potensi intervensi itu justru datang dari pemerintah pada saat pemberlakuan PKPU, disebabkan yang berwenang mengundangkannya ialah menteri di bidang hukum (Menteri Hukum dan HAM) ${ }^{44}$ Padahal, un-

43 Robert A. Dahl, Dilemmas of Pluralist Democracy: Autonomy and Control (New Heaven and London: Yale University Press, 1982), hlm. 18.

44 Pasal 85 UU Nomor 12 Tahun 2011 tentang Pembentukan Peraturan Per- 
tuk berlaku dan mengikatnya suatu perundang-undangan, termasuk PKPU, maka ia harus diundangkan. ${ }^{45}$ Ini artinya bisa saja pemerintah (menteri) mengintervensi KPU dalam penyusunan PKPU dengan imbalan pengundangannya sebagai peraturan perundang-undangan yang berlaku dan mengikat.

Kedua, putusan tersebut meneguhkan independensi KPU sebagai institusi penyelenggara pemilu. Pemilu merupakan upaya untuk mewujudkan pemerintahan dari rakyat, oleh rakyat dan untuk rakyat. Oleh karena itu penyelenggaraan pemilu adalah wujud nyata pengakuan hak asasi manusia dalam kehidupan bernegara yang harus didorong agar pelaksanaannya demokratis. Pemilu akan berjalan demokratis apabila penyelenggara pemilu memegang teguh prinsip independensi dari awal sampai akhir.

\section{Kesimpulan}

Berdasarkan analisis dan pembahasan di atas dapat ditarik kesimpulan sebagai berikut. Pertama, KPU sebagai lembaga negara yang independen diatur secara langsung dalam Pasal 22E UUD NRI Tahun 1945 sebagai organ yang nasional, tetap dan mandiri. Sebagai lembaga negara independen, KPU tidak berada di bawah pengaruh DPR dan pemerintah dalam menjalankan tugas dan wewenangnya. Frasa "mandiri" yang terdapat dalam Pasal 22E UUD NRI 1945 dimaksudkan agar KPU dalam menyelenggarakan pemilu tidak diintervensi oleh pihak lain. Adapun independensi berarti sikap yang tidak bisa dipengaruhi, tidak dikendalikan pihak lain, dan tidak bergantung pada pihak lain. Ia merupakan sifat yang tidak dapat diintervensi oleh pihak manapun, sekalipun dari pemegang kekuasaan tertinggi. Apabila dalam bersikap tersebut ada intervensi oleh suatu lembaga misalnya, maka ia tidak bisa lagi disebut bersifat independen. Oleh karena itu untuk menjamin terjaganya kinerja KPU dalam menjalankan tugas sebagai penyelenggara pemilu prinsip independensi harus dijunjung tinggi. Kedua, implikasi yuridis dalam Putusan 92/

undang-undangan.

45 Pasal 87 UU Nomor 12 Tahun 2011 tentang Pembentukan Peraturan Perundang-undangan. 
PUU-XIV/2016 ialah bahwa ke depan frasa mengikat dalam Pasal 9 huruf A UU Pilkada sudah tidak berlaku lagi dan oleh karenanya KPU dalam membuat peraturan KPU dapat lebih leluasa. Sifat konsultasi dalam rapat dengar pendapat dengan pemerintah dan DPR hasilnya dikembalikan ke KPU untuk menindaklanjutinya. Dengan putusan tersebut, marwah dan independensi KPU sebagai lembaga penyelenggara pemilu dapat terjaga.

\section{Daftar Pustaka}

\section{Artikel/Buku/Laporan}

Amsari, Feri. Perubahan UUD 1945: Perubahan Konstitusi Negara Kesatuan Republik Indonesia Melalui Putusan Mahkamah Konstitusi. Jakarta: Rajawali Pers, 2013.

Asshiddiqie, Jimly. Konstitusi dan Konstitusionalisme Indonesia. Jakarta: Sinar Grafika, cetakan kedua, 2011.

Asshiddiqie, Jimly. Pengantar Ilmu Hukum Tata Negara. Jakarta: Rajawali Pers, 2011.

Asshiddiqie, Jimly. Perkembangan \& Konsolidasi Lembaga Negara Pasca Reformasi. Jakarta: Sinar Grafika, 2012.

Asshiddiqie, Jimly. Pokok-Pokok Hukum Tata Negara Indonesia. Jakarta: BIP Gramedia, 2008.

Dahl, Robert A. Dilemmas of Pluralist Democracy: Autonomy and Control. New Heaven \& London: Yale University Press, 1982.

Gaffar, Afan. Politik Indonesia Transisi Menuju Demokrasi. Yogyakarta: Pustaka Pelajar, 2001.

Garner, Bryan A. Black Law Dictionary. United States of America: West Group, edisi ketujuh, 1999.

Huda, Ni'matul dan R. Nazriyah. Teori \& Pengujian Peraturan Perundang-undangan. Bandung: Nusa Media, 2011.

Irawan, Oktino Setyo. "Analisis Kedudukan Komisi Pemilihan Umum (KPU) Sebagai Lembaga Independen dalam Sistem Ketatanegaraan Indonesia”. Dinamika Hukum, 2, 1 (2011): 75-87.

Mahkamah Konstitusi RI. Hukum Acara Mahkamah Konstitusi. Jakarta:

Sekretariat Jenderal dan Kepaniteraan MK RI, 2010.

Manan, Bagir. Kedaulatan Rakyat, Hak Asasi Manusia dan Negara Hu- 
kum. Jakarta: Gaya Media Pratama, 1996.

Marzuki, Suparman. "Peran Komisi Pemilihan Umum dan Pengawas

Pemilu untuk Pemilu yang Demokratis”. Ius Quia Iustum, 15, 3 (2008): 393-412.

Nasution, Adnan Buyung. Pikiran \& Gagasan Demokrasi Konstitusional. Jakarta: PT Kompas Media Nusantara, 2011.

Nur'aini, "Politik Hukum Larangan Pengunduran Diri Anggota Komisi Pemilihan Umum”. Jurnal Cita Hukum, 2, 1 (2013): 285302.

Purnama, Eddy. Negara Kedaulatan Rakyat. Malang: Nusa Media, 2007.

Siahaan, Maruarar. Hukum Acara Mahkamah Konstitusi Republik Indonesia. Jakarta: Konstitusi Press, 2005.

Tauda, Gunawan A. Komisi Negara Independen. Yogyakarta: Genta Press, 2012.

Thaib, Dahlan. Ketatanegaraan Indonesia Perspektif Konstitusional. Yogyakarta: Total Media, 2009.

Winarti. "Menyoal Independensi dan Profesionalitas Komisi Pemilihan Umum Daerah dalam Penyelenggaraan Pemilu Kepala Daerah”. Jurnal Konstitusi, 2, 3 (2010): 51-84.

\section{Peraturan dan Putusan Hukum}

Mahkamah Konstitusi Republik Indonesia. Peraturan Nomor 08/ $\mathrm{PMK} / 2006$.

Mahkamah Konstitusi Republik Indonesia. Putusan Nomor 92 / PUU$\mathrm{XIV} / 2016$.

Republik Indonesia. Undang-Undang Dasar Negara Republik Indonesia Tahun 1945.

Republik Indonesia. Undang-Undang Nomor 15 Tahun 2011 tentang Penyelenggara Pemilu.

Republik Indonesia. Undang-Undang Nomor 8 Tahun 2015 jo Undang-Undang Nomor 10 Tahun 2016 tentang Pemilihan Gubernur, Bupati dan Walikota.

Republik Indonesia. Undang-Undang Nomor 12 Tahun 2011 tentang Pembentukan Peraturan Per-undang-undangan. 